\title{
The Exploration and Research of Blended Teaching Mode Based on "Internet+" Big Data Cloud Platform
}

\author{
Xiang Ma ${ }^{(\bowtie)}$, Xuhui Fan, Wei Li, Jiangtao Li, and Qiong Li \\ Foundation Department, Engineering University of PAP, Xi'an 710086, China \\ maxiang1309@126.com
}

\begin{abstract}
In the light of problems in online teaching of new coronavirus (2019-nCoV) epidemic period in advanced mathematics curriculum, this paper analyzes the teaching effect of short-term one-way online education mode in the teaching practice of concrete courses by using the real-time data of "rain classroom" teaching management platform. Above that this paper explore and practice the hybrid teaching mode based on "Internet+" big data cloud platform, aiming at promoting the "Internet+Education" information technology and curriculum teaching depth integration, improving the teaching effect, and promoting education and teaching reform.
\end{abstract}

Keywords: Advanced mathematics $\cdot$ Teaching mode $\cdot$ Rain class $\cdot$ Internet+

\section{Introduction}

With the development of educational technology, the updating of educational mode and the change of talent demand, the current teaching mode of college [1,2] mathematics has been challenged severely. In particular, with the new coronavirus (2019-nCoV) outbreak in large areas of the world, forcing offline education to temporarily halt. In the "epidemic" impact, the current teaching situation will push back the teaching philosophy must be further updated. At the same time, the teaching situation must require the integration of specific curriculum teaching and online teaching, drive the coordinated development of educational resources in the whole society, promote the reform of information teaching to be concrete, deep and universal, and then promote a new round of teaching mode [3-5] reform to the deep water area. At this time, a large number of scholars, educators are conducting in-depth thinking and exploration. This paper is aimed at the exploration and practice of online teaching of Advanced Mathematics, and analyzes the new problems in the process of implementing "Rain Classroom" platform in curriculum teaching. A hybrid teaching model based on "Internet+" big data is put forward in order to improve the teaching quality of new-type compound talents. 


\section{Current Situation and Analysis of Online Teaching Model}

\subsection{The Development Process of Online Teaching Model in China}

Since the 1970s, China has established radio and television universities in various parts of the country [6]. The use of satellite technology for distance learning to meet the needs of social workers to learn, to obtain diploma. With the development of science and technology, distance education is challenged severely. In 2012, the National Open University was officially established, and the original Radio and Television University has been suspended or transformed into a local Open University. As a result, an open university system with Chinese characteristics has been initially formed. Based on this, 2012 is also known as China's "first year of MOCs". With the further development of science and technology, there are many forms of online courses, such as Micro-Course [7], MOOC [8,9] and SPOC [10]. In order to better regulate the ecology of online education, in April 2018, the Ministry of Education issued the "Action Plan for Education Informatization 2.0", which promotes the rapid development of online education based on the "Internet+Education" platform. However, the exploration of online teaching mode for mathematics curriculum has not obtained the universal law, and its teaching effect has not been verified by the teaching practice on a large scale. China first began the "suspension of classes non-stop learning" teaching model, With a new coronavirus outbreak in the world by 2020 . As a result, online education has been carried out in an all-round way in China, which provides the possibility for online teaching practice verification.

\subsection{The Current Situation of Online Teaching Mode of Advanced Mathematics}

This paper based on the teaching management platform of "rain classroom", the course of Higher Mathematics uses the data obtained by online teaching, and utilizes the method of comparative analysis to get the following results, as shown in Fig. 1.

Through the data analysis [11], we can conclude that the students' satisfaction with the online learning platform is high, which fully shows that the online teaching platform has played a supporting role in the teaching of higher mathematics courses [2]. At the same time, the analysis results also reflect some problems in online teaching. "Live Video" is the Main Form of Online Teaching used by teachers, however, students rarely use watching "MOOC" for self-study, which shows that personalized learning experience is the focus of students. The online interactive seminar did not achieve the expected results, which shows that it is very important to answer questions and provide tutoring to ensure the quality of teaching. Teachers provide materials students selfstudy popularization rate is low, indicating that the preparation stage of online teaching still needs to be improved. The assignment of homework is more frequent, which shows that online teaching does not really reduce the teaching burden of teachers and students. 


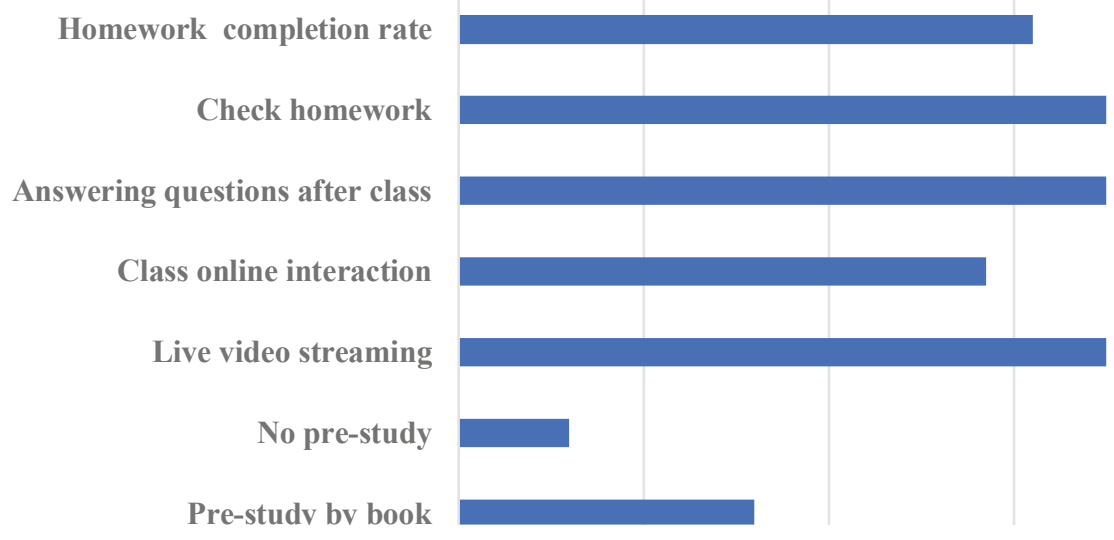

Fig. 1. The current situation of online teaching.

\subsection{The Analysis of the Current Situation of the Online Teaching Mode of Advanced Mathematics}

The development of online education is based on the theory of constructivism. It is a teaching organization activity in which teachers rely on the network platform to complete the teaching task and achieve the teaching goal according to the teaching plan. This model can make up for the shortcomings of traditional teaching, and to a large extent can satisfy the public education, especially the vocational education. Especially in the "2019-nCoV epidemic" period, online education shows its strong advantages. In addition, during the special period of 2019-nCoV epidemic, online education shows strong advantages. At the same time, online education also has many disadvantages. The advantages and disadvantages of online teaching mode are analyzed and compared as shown in Table 1.

Advanced Mathematics belongs to the basic course of culture in colleges and universities. The course has a high degree of abstraction, rigorous logic and wide application. For course contents involving calculation, proof and logical reasoning, students prefer the classroom teaching mode of gradual deduction and calculus display by the blackboard. But for some courses that are more closely related to life, students prefer teachers to use experimental demonstration or dynamic display with the help of network resources. Thus, the two different teaching modes cannot fully adapt to different teaching contents.

Online teaching can help students to expand their knowledge with the help of online high-quality resources, let the students acquire learning knowledge anytime, anywhere, conveniently and quickly, and students adjust their learning progress in real time according to their learning situation. Traditional classroom teaching is helpful for students to acquire learning knowledge systematically, comprehensively and efficiently in a short time, and it can cultivate students' systematic, logical and creative thinking mode, at the same time, cultivate students' emotional values and mold complete independent personality. 
Table 1. Advantages and disadvantages of online teaching model

\begin{tabular}{|c|c|c|}
\hline $\begin{array}{l}\text { Online teaching } \\
\text { based on "rain } \\
\text { classroom" }\end{array}$ & Teaching advantage & Teaching inferiority \\
\hline $\begin{array}{l}\text { Teaching } \\
\text { resources }\end{array}$ & $\begin{array}{l}\text { Numerous teaching resources and } \\
\text { platforms. Such as: MOOC of } \\
\text { Chinese university, school online, } \\
\text { NetEase open course etc. }\end{array}$ & $\begin{array}{l}\text { Online resources are numerous, } \\
\text { which makes it difficult for students } \\
\text { to choose suitable learning resources } \\
\text { effectively }\end{array}$ \\
\hline \multirow[t]{3}{*}{ Teacher aspects } & $\begin{array}{l}\text { Advantageous to improve the } \\
\text { computer operation ability of } \\
\text { teachers and the application of } \\
\text { software skills }\end{array}$ & $\begin{array}{l}\text { Spend a lot of energy and money to } \\
\text { make courseware and screen } \\
\text { resources }\end{array}$ \\
\hline & $\begin{array}{l}\text { Receive real-time feedback from all } \\
\text { participants online learning with the } \\
\text { help of "rain class" }\end{array}$ & $\begin{array}{l}\text { It cannot good for teachers to adjust } \\
\text { teaching status in real time due to the } \\
\text { lack of face-to-face communication }\end{array}$ \\
\hline & $\begin{array}{l}\text { Teachers can make full use of } \\
\text { network resources, multi- } \\
\text { dimensional multi-level better } \\
\text { display teaching content }\end{array}$ & $\begin{array}{l}\text { Cannot effectively monitor the } \\
\text { teaching implementation process, for } \\
\text { ensure the teaching effect }\end{array}$ \\
\hline \multirow[t]{3}{*}{ Student aspects } & $\begin{array}{l}\text { Fully mobilize the enthusiasm of } \\
\text { students to learn, realize students as } \\
\text { masters, improve the quality of } \\
\text { teaching }\end{array}$ & $\begin{array}{l}\text { Virtual network environment is not } \\
\text { conducive to cultivating students' } \\
\text { sense of cooperation, competition } \\
\text { and discipline }\end{array}$ \\
\hline & $\begin{array}{l}\text { Encourage students to use mobile } \\
\text { phones to actively use active learning }\end{array}$ & $\begin{array}{l}\text { This cannot improve cultivating } \\
\text { students' emotional values and } \\
\text { personality building with the cold } \\
\text { computer interface }\end{array}$ \\
\hline & $\begin{array}{l}\text { It is helpful for students to choose } \\
\text { their own learning style, learning } \\
\text { materials and learning progress } \\
\text { according to their actual learning } \\
\text { situation }\end{array}$ & $\begin{array}{l}\text { This teaching model is bad to the } \\
\text { growth of the students with poor self- } \\
\text { control ability, because it requires } \\
\text { higher self-control ability of the } \\
\text { students }\end{array}$ \\
\hline \multirow[t]{4}{*}{$\begin{array}{l}\text { Integrated } \\
\text { aspects }\end{array}$} & $\begin{array}{l}\text { This model can improve the quality } \\
\text { of the people, so as to achieve } \\
\text { comprehensive learning and lifelong } \\
\text { learning }\end{array}$ & $\begin{array}{l}\text { High requirements for hardware and } \\
\text { software facilities, network signal } \\
\text { transmission and environmental } \\
\text { factors }\end{array}$ \\
\hline & $\begin{array}{l}\text { Fragmentary knowledge is helpful } \\
\text { for students to make full use of } \\
\text { learning knowledge }\end{array}$ & $\begin{array}{l}\text { There are many problems in online } \\
\text { teaching, such as network security, } \\
\text { signal transmission, course charge, } \\
\text { etc. }\end{array}$ \\
\hline & $\begin{array}{l}\text { Better Teaching Work in Rural } \\
\text { Remote and Poor Schools }\end{array}$ & $\begin{array}{l}\text { The teaching effect is poor because } \\
\text { there is no blackboard }\end{array}$ \\
\hline & $\begin{array}{l}\text { Effective educational models for } \\
\text { special times (e.g., global outbreak of } \\
\text { 2019-nCoV in 2020) }\end{array}$ & $\begin{array}{l}\text { The teaching contents are } \\
\text { fragmentary and lack of } \\
\text { systematization, which is cannot } \\
\text { cultivate students' systematic } \\
\text { thinking, logical thinking and } \\
\text { associative creative thinking }\end{array}$ \\
\hline
\end{tabular}


Therefore, if we can integrate the advantages of online teaching and offline teaching organically, and explore a hybrid teaching mode in line with the characteristics of higher mathematics curriculum, and then apply it to teaching practice to improve the teaching effect, it is beneficial for the realization of teaching objectives and the improvement of teaching quality.

\section{Blended Teaching Mode}

Based on the teaching practice and research of "Advanced Mathematics", this paper proposes a blended teaching mode based on "Internet+" Big Data Cloud Platform for Classroom Teaching and Online Teaching [12] (As shown in Fig. 2).

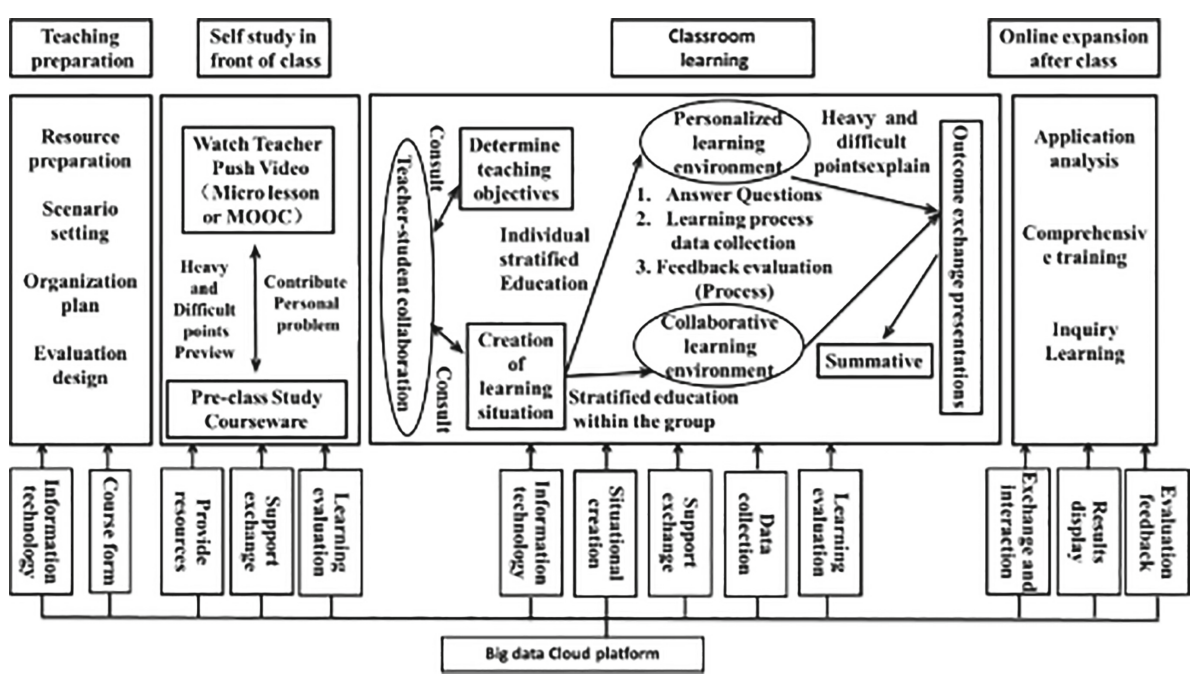

Fig. 2. Blended teaching model based on "Internet+".

As shown in Fig. 3, In the process of teaching, there are three stages: pre-class, inclass and after-class. Before class, teachers send class announcements, push preview courseware through the online platform, and improve pre-class preparation work. In this way, students can be familiar with the key and difficult points in this course in advance, and can find materials before class, preview in advance, and change passive acceptance learning into active exploration learning, which is beneficial for students with different levels of cultural foundation to prepare for different situations before class, so as to enhance students' learning enthusiasm and improve the teaching quality and effectiveness of the course in the teaching process. In the class, it mainly uses the form of classroom intensive lecture or classroom discussion to teach the teaching content of special period or special chapter can also use the online teaching mode), so as to realize the new teaching mode with students as the main body and teachers as the leading role, so as to promote students to become the protagonists of learning and 
teachers to become the guiders of students' growth. Finally, in view of the deficiencies in the learning process of students, through the after-school Q \& A and after-school test and comment link to check the deficiencies and make up the omissions, improve the teaching process.

According to the different actual situation, the blended teaching mode has many different methods of organization and implementation. Advanced Mathematics Course is organized on the Platform of "Rain Classroom", In this paper, the researchers deeply think and analysis, and put forward the exploration and research of the mixed teaching mode from the following dimensions.

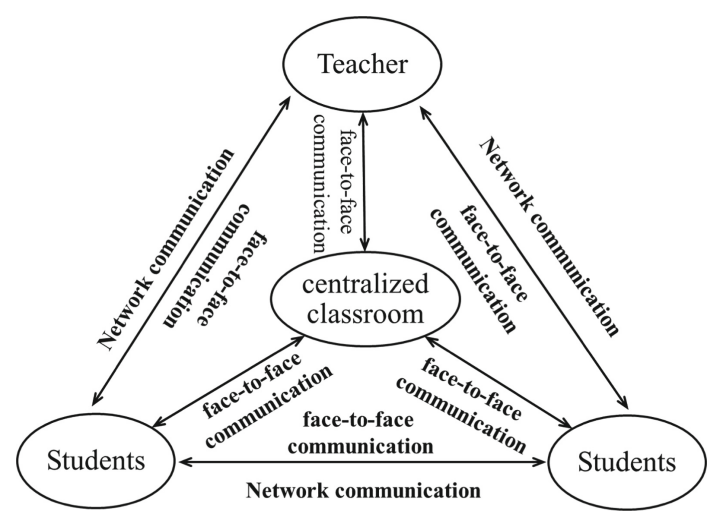

Fig. 3. Chart of implementation of mixed teaching model

In the course, based on the classroom teaching, the rain classroom screen recording mode is adopted to integrate the online and offline teaching process. First of all, when confronted with a difficult problem, the students expressed their confusion by sending shrapnel. According to the cue of bullet screen combined with the students' expressions, the teacher adjusted the teaching status in time to answer the students' doubts. Secondly, with the help of network platform, it is convenient to record the data of students' learning in class. Finally, the recording software can record the whole teaching process, which is convenient for students to review after class and listen to the course content repeatedly.

Through the combination of online and offline models, teachers can count the subjects with high error rate and elaborate in the classroom. We explain these topics precisely in class. For a small number of topics with low error rate, teachers use the way of recording and explaining videos to push to everyone online, students with a weak foundation can check the explanation of the corresponding topic according to their actual situation. 


\section{Practice and Evaluation of Blended Teaching Mode in the Course of Advanced Mathematics}

This paper selects "spatial curve and its equation" as the teaching content, combines with the analysis of learning situation, adopts the mixed teaching mode to design the teaching content, and carries out the teaching evaluation based on the background data of "rain class", in order to test the teaching effect of the above mixed teaching mode.

\subsection{Teaching Content}

"Spatial curves and its equations" are the important geometric basis for supporting the calculus module of multivariate functions. It is located in the sixth section of the eighth chapter of seventh of the Advanced Mathematics Curriculum edition, Tongji University (Volume Two). Before that, students have been familiar with plane curves and have learned special curves - straight lines and their equations, which paves the way for this lesson.

\subsection{Academic Analysis}

Civil Engineering Students Selected as Teaching Objects in This Class. The students are in good learning condition, active in thinking and strong in practical operation, but their basic knowledge is weak, and lack the ability of independent analysis and independent inquiry learning. Before learning, students have known about space straight line and plane curve, but they don't know about space curve.

In view of these characteristics of students, using the form of online exercise test, teachers can detect the student's spatial analytic geometry of the basic knowledge grasp.

\subsection{Three-Dimensional Learning Goals}

According to the talent training plan and the implementation plan of advanced mathematics course, combined with students' cognitive psychological characteristics, the teaching objectives of this course are determined as follows (Table 2): 
Table 2. Three-dimensional learning goals

\begin{tabular}{l|l}
\hline Knowledge & $\begin{array}{l}\text { The general equation of space curve and parameter equation should be } \\
\text { mastered by students }\end{array}$ \\
\hline $\begin{array}{l}\text { They should be mastered by the students with Knowledge of the } \\
\text { projection of intersecting lines of a space surface on a coordinate plane }\end{array}$ \\
\hline Capjectives & $\begin{array}{l}\text { Students were able to establish the relationship between spatial curves and } \\
\text { equations, in their minds, geometry is presented. Their spatial imagination } \\
\text { is enhanced }\end{array}$ \\
\hline $\begin{array}{l}\text { With the help of the combination of numbers and shapes, students have } \\
\text { improved their ability to use advanced mathematics theory, knowledge } \\
\text { and skills to solve practical problems }\end{array}$ \\
\hline Emotional goals & $\begin{array}{l}\text { The interest of the students is stimulated by the study of mathematic. } \\
\text { Students' desire to explore independently is satisfied. They are eager to } \\
\text { study the quantitative relationship in the natural environment }\end{array}$ \\
\hline $\begin{array}{l}\text { They were able to appreciate the connection between mathematics and } \\
\text { reality. They experienced the process of mathematical knowledge being } \\
\text { discovered and created }\end{array}$ \\
\hline $\begin{array}{l}\text { Dialectical materialism is accepted by the students and patriotic sentiment } \\
\text { is aroused }\end{array}$ \\
\hline
\end{tabular}

\subsection{Teaching Implementation Process}

See Table 3.

Table 3. Practice of hybrid teaching model

\begin{tabular}{l|l}
\hline Teaching module & Implementation steps \\
\hline Preparation before class & $\begin{array}{l}\text { The teacher issues the teaching announcement and pushes the } \\
\text { teaching video of space curve in MOOC Advanced } \\
\text { Mathematics (IV) of National University of Defense Science } \\
\text { and Technology }\end{array}$ \\
\hline $\begin{array}{l}\text { Through the "Rain classroom" teaching platform to publish } \\
\text { preview courseware, students can intuitively feel the shape of } \\
\text { the space curve according to the specific pictures given in the } \\
\text { courseware (such as the deck of an aircraft carrier, Bird Nest, } \\
\text { Beijing Daxing International Airport) }\end{array}$ \\
\hline $\begin{array}{l}\text { The Preview Courseware of "Rain Class" has the function of } \\
\text { testing. Teachers can use this feature to test students' previews }\end{array}$ \\
\hline $\begin{array}{l}\text { In the rain classroom platform, students are divided into groups } \\
\text { according to their learning situation. They solve problems in } \\
\text { collaboration }\end{array}$ \\
\hline
\end{tabular}


Table 3. (continued)

\begin{tabular}{|c|c|}
\hline Teaching module & Implementation steps \\
\hline \multirow[t]{9}{*}{$\begin{array}{l}\text { Implementation process in } \\
\text { the classroom }\end{array}$} & $\begin{array}{l}\text { 1. According to the preparation before class, teachers comment } \\
\text { on the effect of preview }\end{array}$ \\
\hline & $\begin{array}{l}\text { 2. The teacher explained the concept of general equations of } \\
\text { spatial curves Parametric Equation of Space Curve in the class }\end{array}$ \\
\hline & $\begin{array}{l}\text { 3. Collaborative group discussions: } \\
\text { Question } 1\left\{\begin{array}{l}z=\sqrt{a^{2}-x^{2}-y^{2}} \\
\left(x-\frac{a}{2}\right)^{2}+y^{2}=\frac{a^{2}}{4}\end{array} \text { express what kind of curve? }\right. \\
\text { Question 2: Space moving point } \mathrm{M} \text { on the cylindrical surface } \\
x^{2}+y^{2}=a^{2} \text { at angular velocity } \omega \text { around Z-axis rotation and } \\
\text { linear velocity v along the parallel direction to Z-axis, point } \mathrm{M} \\
\text { motion locus is called helix. Try to establish its parametric } \\
\text { equation }\end{array}$ \\
\hline & $\begin{array}{l}\text { 4. Organize group evaluations Conclusions of Questions } \\
\text { Explored before Class }\end{array}$ \\
\hline & $\begin{array}{l}\text { 5. The teacher summed up the problem and extend it } \\
\text { Expand 1: Use 3D dynamic pictures to show Viviani curve, and } \\
\text { ask students to find other life examples } \\
\text { Expand 2: Change the pitch of the cylindrical helix to produce a } \\
\text { conical helix and display it using 3D dynamic images, and ask } \\
\text { students to find other life examples }\end{array}$ \\
\hline & $\begin{array}{l}\text { 6. Collaborative group discussions: } \\
\text { (1) How to Draw a Space Curve on a Plane? } \\
\text { (2) Find the projection of the space curve C on the } \\
\text { xoy coordinate plane }\end{array}$ \\
\hline & $\begin{array}{l}\text { 7. The teacher summarized the projection methods and } \\
\text { explained their application in engineering drawing }\end{array}$ \\
\hline & $\begin{array}{l}\text { 8. For some engineering objects, the students explored their } \\
\text { projections on different coordinates }\end{array}$ \\
\hline & $\begin{array}{l}\text { 9. According to the teaching contents of this class, teachers and } \\
\text { students summed up the methods to deal with practical } \\
\text { problems }\end{array}$ \\
\hline \multirow[t]{2}{*}{ After-school evaluation } & $\begin{array}{l}\text { Release the homework after class through the teaching } \\
\text { platform of "Rain Classroom" }\end{array}$ \\
\hline & $\begin{array}{l}\text { Through the "rain classroom" teaching platform to promote the } \\
\text { development of resources: such as the application of "Mu He } \\
\text { Fang Gai" (for example CCTV standard, mechanical } \\
\text { engineering components) }\end{array}$ \\
\hline
\end{tabular}

\subsection{Teaching Evaluation}

According to the results of the exercises in the preview courseware, we can evaluate [13] the students' preview effect. 
According to the correct rate of the time-limited questions sent in class, we can evaluate the students' mastery of knowledge.

According to the time-limited examination papers sent online after class, we can test the students' learning effect.

\section{Conclusion}

Based on the teaching practice of higher mathematics, relying on the "Internet+" big data cloud platform and using the "rain classroom" information technology, this paper innovates the teaching mode, to promote students to become the initiator of learning, the organizer of seminars and even the innovator of knowledge application. This is bound to break the original knowledge system and framework structure, so as to promote the education reform to a deeper level so that the teaching quality, the teaching effect as well as the docking social demand will make the breakthrough progress.

\section{References}

1. Lee, J., Jin, C., Liu, Z.: Predictive big data analytics and cyber physical systems for TES systems. In: Advances in Through-Life Engineering Services, pp. 97-112 (2017)

2. Dees, D.M., Ingram, A., Kovalik, C., et al.: A transactional model of college teaching. Int. J. Teach. Learn. High. Educ. 19, 130-140 (2007)

3. Song, C., Yu, Q.: Research on project-based teaching model based on flipped classroom. J. Distance Educ. 1, 96-104 (2013)

4. Sams, A.: The flipped classroom. In: 242nd National Meeting of the American-ChemicalSociety (ACS), 28 August-01 September 2011 (2011)

5. Lage, M., Platt, G., Treglia, M.: Inverting the classroom: a gateway to creating an inclusive learning environment. J. Econ. Educ. 31(1), 30-43 (2000)

6. Wu, H.: Research on mixed teaching of ideological and political course in open university. Guangzhou University (2019)

7. Lin, Q.: Exploration and research on teaching mode of computer micro course. J. Anqing Normal Univ. (Nat. Sci. Ed.) 26, 116-118 (2020)

8. Memon, A.R., Mavrinac, M.: Knowledge, attitudes, and practices of plagiarism as reported by participants completing the AuthorAID MOOC on research writing. Sci. Eng. Ethics 26, 1067-1088 (2020)

9. Kiselev, B., Yakutenko, V.: An overview of massive open online course platforms: personalization and semantic web technologies and standards. Procedia Comput. Sci. 169, 373-379 (2020)

10. Zhao, W., Zhou, G., Liu, X.: Study on the feasibility of SPOC mixed teaching model in higher mathematics classroom of military academy. Educ. Teach. Forum 12, 282-284 (2020)

11. Wu, D.: Investigation report on online learning of college students during epidemic. Fujian, Bruce, CIQA and Xiamen University Teacher Development Center (2020)

12. Yan, Z., Xu, J.: Research on personalized teaching mode of "Internet+" integration of online and offline. Chin. Vocat. Tech. Educ. 5, 74-78 (2016)

13. Yang, M.: Research on teaching mode of microbial pharmaceutical technology. J. Educ. Res. Polic. (JERP) 2, 27-28 (2020) 